\title{
アーク溶融法によるポルーサイト質ガラスセラミックスの合成と焼結体の作製
}

\author{
宮川直通・篠原伸広・奥宮正太郎 \\ 旭硝子(侏)中央研究所, 221-0863 横浜市神奈川区羽沢町 1150
}

\section{Synthesis and Fabrication of Pollucite Glass-Ceramics by Using Arc Melting Technique}

Naomichi MIYAGAWA, Nobuhiro SHINOHARA and Masataro OKUMIYA

Research Center, Asahi Glass Co., Ltd., 1150, Hazawa-cho, Kanagawa-ku, Yokohama-shi 221-0863

\begin{abstract}
Synthesis and fabrication of pollucite glass-ceramics was investigated. The mixture which was measured to be the stoichiometric ratio of pollucite was melted by using an arc melting technique to synthesize the material in glass state. Milled powder of the glass was mold pressed and CIPed to obtain green compacts. Dense pollucite glass-ceramics were obtained by heat-treating the compact at $1400^{\circ} \mathrm{C}$ for $4 \mathrm{~h}$ in air. Enhanced densification of the present material was ascribed to the viscous deformation of the glass phase. Fracture strength and the Young's modulus of the resultant pollucite glass-ceramies were $102 \mathrm{MPa}$ and $100 \mathrm{GPa}$ at room temperature, respectively. Average fracture strength exhibited $128 \mathrm{MPa}$ for specimens measured at $1000^{\circ} \mathrm{C}$. Thermal expansion coefficient of the sample was $2.7 \times 10^{-6} /{ }^{\circ} \mathrm{C}$ between room temperature and $1000^{\circ} \mathrm{C}$ [Received November 25, 1998; Accepted April 22, 1999]
\end{abstract}

Key-words : Pollucite, Thermal expansion, Densification, Arc melting technique, Viscous deformation

\section{1. 緒 言}

低熱膨張セラミックスは優れた耐熱衝撃性を有しており，高 温集塵フィルター, 溶融金属用部材, 熱処理用部材などとして 幅広く使用されている. 代表的な低熱膨張材料としてはコー ディエライト, $\beta$-スポジュメン, ユークリプタイト, チタン酸 アルミニウムなどが知られている。しかし，これらの材料はい ずれも耐熱性が低く, 添加剤にもよるがコーディエライトでも 安定して使用できる領域は $1000 \sim 1200^{\circ} \mathrm{C}$ 考えられる. 一方, 高温集塵フィルターなどでは未然物の異常燃焼などにより局所 的に $1200^{\circ} \mathrm{C}$ 超える温度が発生することがあるため, 材料の 耐熱性の向上が望末れている. $1200^{\circ} \mathrm{C}$ 以上高温で使用可能 な低熱膨張セラミックスの一つとしてポルーサイト $\left(\mathrm{Cs}_{2} \mathrm{O}\right.$. $\mathrm{Al}_{2} \mathrm{O}_{3} \cdot 4 \mathrm{SiO}_{2}$ ）が挙げられる1). ポルーサイトの結晶構造は室

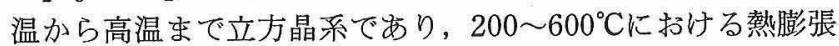
はほぼゼロに近いという優れた特性が報告されている6),10). し かし，ポルーサイトの溶融合成には $1900^{\circ} \mathrm{C}$ 以上の温度を必要 とすることが報告されており2，通常の合成方法では工業的レ ベルで要求されるような大量の原料合成は困難である, また, 本材料の粉末合成 ${ }^{3), 4)}$, 熱膨張挙動5) 7)についてはいくつかの 報告例があるが，いずれも粉末に関するものであり，焼結体の 特性についてはほとんど知られていない。

著者らは,ポルーサイトの合成に対してアーク溶融法の適用 を試みた。アーク溶融法は $3000^{\circ} \mathrm{C}$ 以上の温度の発生が可能で あり，1900 $\mathrm{C}$ 以上合成温度が必要とされるポルーサイト組 成ガラスの大量合成に適した方法と考えられる. 更に, 得られ た非晶質原料を用いて焼結体の作製を試みた結果, 維密なポ ルーサイト質焼結体が得られる可能性が見いだされた。また熱 的，機械的特性の測定も行ったので，以下にその結果について 報告する。

\section{2. 実験方法}

出発原料には, セシウム源として $\mathrm{Cs}_{2} \mathrm{CO}_{3}$ (第一稀元素化学 工業製), アルミナ, シリカ源として $\mathrm{Al}_{2} \mathrm{O}_{3}$ (住友化学工業製, $\mathrm{AKP}-20), \mathrm{SiO}_{2}$ (関東化学製) を使用した. 熱処理後にポルー サイトの量論比となるように乾式により $1 \mathrm{~h}$ 混合後, 混合原料
を図 1 に示したようなジルコニア鋳造耐火物を内張りしたアー ク溶融师に投入し, 溶融を行った. 未溶融物の残留を防止する ため, 通電した状態で $10 \mathrm{~min}$ 保持して十分に溶融した後, 溶 融物を水中に投入して急冷させ，ガラス体を得た．得られたガ ラスについて，原子吸光法及び ICP 発光分析法による組成分 析, X線回折法による非晶質相の確認と熱処理後の結晶相の 同定，TG-DTAによるガラス軟化点及び結晶化温度の測定を 実施した. また，得られたガラスを粗粉砕機，乳鉢を用いて $1 \mathrm{~mm}$ 以下にした後, 遊星ボールミルによりアルミナボールを 用いて粉砕し，焼結用原料とした．粉碎後の粉末に対しては レーザー回折散乱法による粒度分布の測定を行った．その粉末 の平均粒径は $2.06 \mu \mathrm{m}$ であった.

ガラス粉末を $60 \times 60 \mathrm{~mm}$ の金型に充媜し，19.6 MPa の圧 力で予備成形した後, $147 \mathrm{MPa}$ の圧力で CIP 成形を行い, 成 形体を得た。焼成は電気炉を用いて $900 \sim 1600^{\circ} \mathrm{C}$ 温度範囲で 大気中で実施した。焼成時間は $4 \mathrm{~h}$ とした。 得られた焼結体に 対してアルキメデス法による密度の測定, 粉末 X 線回折法に よる結晶相の同定, 走査型電子顕微鏡 (SEM) による微細構 造の観察を行った. 熱膨張率は, 焼結体から $5 \times 5 \times 20 \mathrm{~mm}$ の 試験片を切り出した後, それを用いて室温から $1000^{\circ} \mathrm{C}$ 範囲 で測定した. 強度测定については, JIS R1607 に従って焼結体

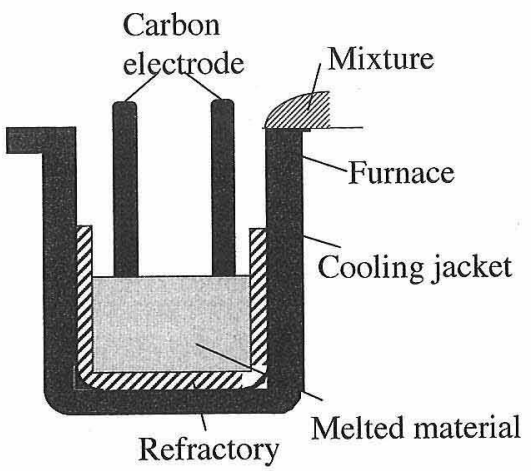

Fig. 1. Schematic illustration of the arc melting furnace. 
から切断及び＃800の砥石による研削加工によって $3 \times 4 \times 35$ $\mathrm{mm}$ の試験片を作製し，スパン $30 \mathrm{~mm}$ の 3 点曲げ法により実 施した. なた, 同じく焼結体から幅 $10 \mathrm{~mm}$, 厚さ $1 \mathrm{~mm}$ の試 験片を切り出し, 室温弾性率の測定を行った。測定はJIS R1602に従い, 試験片の引張り面に歪みゲージを貼付し, 曲げ 強度測定における最大荷重の70\%をで負荷をかけた際の歪み 量から弾性率を算出した。

\section{3. 結果及び考察}

図 2 に得られた溶融物の熱処理前後の粉末 $\mathrm{X}$ 線回折パター ンを示す．得られた溶融物は透明であり，また相同定の結果か らは出発原料の残留を示すアルミナ, シリカ等の結晶相のピー クは認められず，良好な非晶質相であると判断された。 また， $1400^{\circ} \mathrm{C}$ で熱処理した粉末からは立方晶ポルーサイトの回折パ ターンのみが検出されている.これらは, アーク溶融法という プロセスにより, ポルーサイトのような高融点を持つ物質でも ガラス相の合成が可能であることを示している.

表 1 にガラスの組成分析の結果を示す. 本実験により得られ たガラスでは, ポルーサイトの量論比と比べて $\mathrm{Cs}_{2} \mathrm{O}$ の含有率 が低くなっていることが分かった. 溶融合成時におけるセシウ 厶成分の低下については，抵抗加熱式の電気炉を用いて合成を 試みた Beall とRittler によっても報告されており2)，溶融中に おけるセシウム酸化物の蒸発が原因とされている.これはセシ ウム酸化物は沸点が $900^{\circ} \mathrm{C}$ 程度 ${ }^{12)}$ と低いために, ポルーサイ
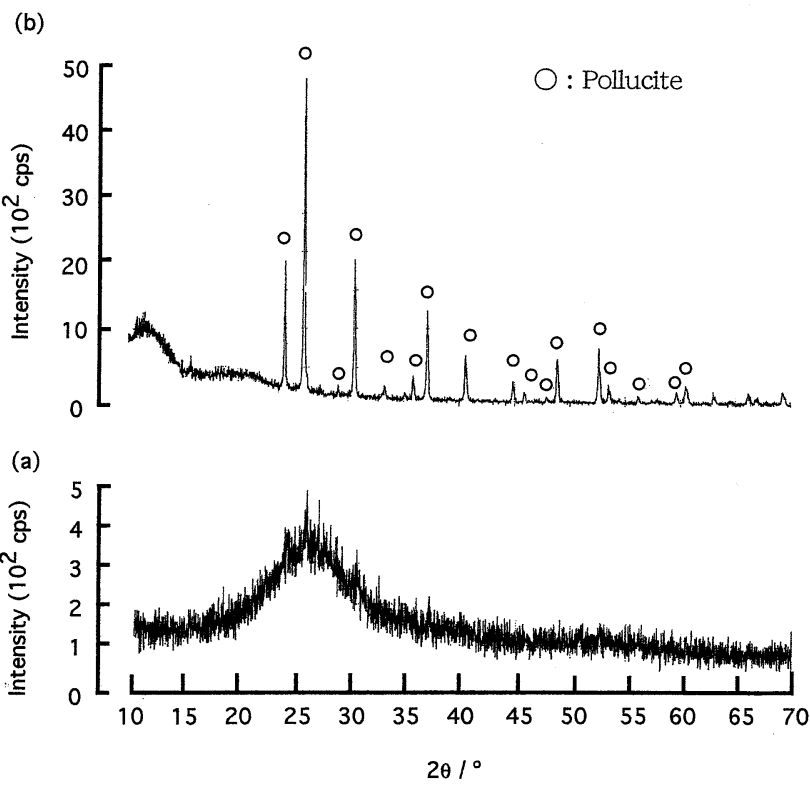

Fig. 2. X-ray diffraction patterns of melted glass and heat-treated sample. (a) Melted glass, (b) crystal phase after heat treatment at $1400^{\circ} \mathrm{C}$ for $4 \mathrm{~h}$ in air.

Table 1. Chemical Composition of the Glass-Melted by Using Arc Melting Technique

\begin{tabular}{|l|c|c|c|c|}
\hline & $\mathrm{Cs}_{2} \mathrm{O}$ & $\mathrm{Al}_{2} \mathrm{O}_{3}$ & $\mathrm{SiO}_{2}$ & $\mathrm{ZrO}_{2}$ \\
\hline $\begin{array}{l}\text { Stoichiometric } \\
\text { ratio (mol\%) }\end{array}$ & 16.7 & 16.7 & 66.6 & \\
\hline Sample & 9.04 & 18.71 & 71.82 & 0.43 \\
\hline
\end{tabular}

トの溶融に必要とされる $1900^{\circ} \mathrm{C}$ 以上の高温加熱中に揮発し, $\mathrm{Cs}_{2} \mathrm{O}$ 量が低下したものと考えられる．特に，本実験で採用し たアーク溶融法は, 電極付近では溶融温度よりかなり高い温度 になっていると予想され， $\mathrm{Cs}_{2} \mathrm{O}$ 成分の減少が促進されたと推 察される. 図 2 に示す X 線回折の結果からは熱処理後の試料 中には結晶相としてポルーサイト相のみが検出された. しかし, $20^{\circ}$ 以下の低角度側で, 比較的高い強度のガラスのハローが確 認され，この表 1 及び図 2 の結果を考慮すると，熱処理後の 本材料中にはポルーサイト結晶以外に多量のガラス質相が残留 していることが考えられる．表 1 に示した結果を基に，すべ ての $\mathrm{Cs}_{2} \mathrm{O}$ が量論比のポルーサイト形成に寄与したと考える と, ジルコニアの存在を無視すれば，焼結後は $\mathrm{Cs}_{2} \mathrm{O} \cdot \mathrm{Al}_{2} \mathrm{O}_{3}$. $4 \mathrm{SiO}_{2}: \mathrm{Al}_{2} \mathrm{O}_{3}: \mathrm{SiO}_{2}=9.04: 9.67: 35.66$ のル比で存在してい ることになる。これを重量比に換算すると64.33: 11.24 : 24.43 となり，約 35 mass\%のアルミナ，シリカ成分がガラス 相を形成していると考えられる. しかし，ポルーサイトの組成 幅について小林らは, $\mathrm{SiO}_{2}$ を基準として $\mathrm{Al}_{2} \mathrm{O}_{3} / \mathrm{SiO}_{2}$ はモル比 で0.96 2.38/4, $\mathrm{Cs}_{2} \mathrm{O} / \mathrm{SiO}_{2}$ はモル比で0.91 1.02/4 とシリ カ, アルミナについて組成幅が広く9), 特にシリカ単独での組 成幅は, 量論比 $\mathrm{Cs}_{2} \mathrm{O}: \mathrm{Al}_{2} \mathrm{O}_{3}: \mathrm{SiO}_{2}=1: 1: 4$ に対し, $1: 1$ : 5.5 と最大で量論組成中のシリカ量に対して $37.5 \%$ 増加しても ポルーサイト単一相 ${ }^{10)}$ が得られることを報告している。これ らの報告を考慮すれば，本実験で得られたポルーサイト質ガラ スセラミックスの残留ガラス相量は, 量論比から算出した量よ りも少なくなることが予想される.

図 3 に，合成したガラス原料粉末から作製した試料の焼成温 度に対するかさ密度の变化を示す. $1200^{\circ} \mathrm{C}$ 以上の温度での焼 成により密度が急激に上昇し， $1400^{\circ} \mathrm{C}$ で最大值 $\left(2.85 \mathrm{~g} / \mathrm{cm}^{3}\right)$ を示した. 残留ガラス相の密度を, アルミナ/シリカ比から文 献17)を参考に推算するとおよそ $2.8 \mathrm{~g} / \mathrm{cm}^{3}$ という值が得られ， これと報告されているポルーサイトの密度 $\left.2.9 \mathrm{~g} / \mathrm{cm}^{3} 8\right)$ を考慮 すると, $2.85 \mathrm{~g} / \mathrm{cm}^{3}$ はほぼ加成則に基づいた值に近い值であ ると推察される.

$1200^{\circ} \mathrm{C}$ 以上での急速な密度の上昇は, ガラスの軟化による 粘性流動機構によるものと考えられる. 図 4 に原料ガラス粉末 の DTA 曲線を示す．図から，本ガラス粉末の軟化温度及び結 晶化温度はそれぞれ $990,1140^{\circ} \mathrm{C}$ 付近にあることが示され，緻

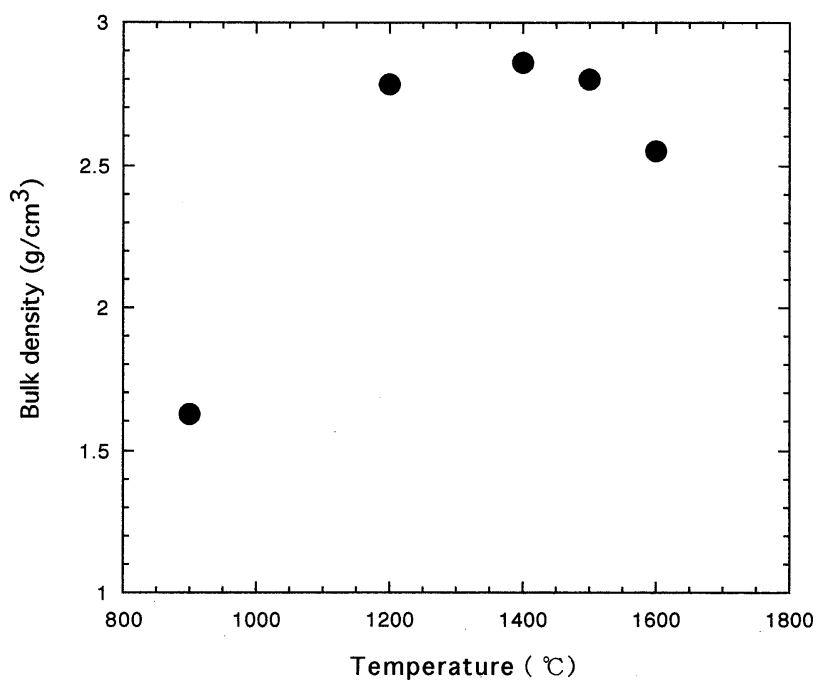

Fig. 3. Relationship between sintering temperature and bulk density of pollucite ceramics. 


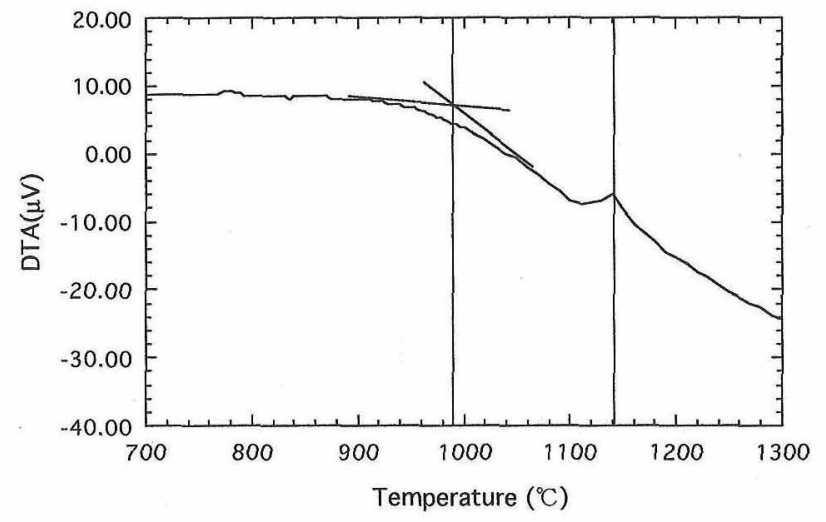

Fig. 4. DTA curve of the glass.

密化に及ぼす粘性流動の寄与を示唆している。また，図 5 に $1400^{\circ} \mathrm{C}$ で焼結した試料の破断面の SEM 写真を示す。破面から は焼結体を構成する粒子の粒界が明確には認められず，本焼結 体がガラスの粘性流動によって緻密化が達成されたガラスセラ ミックスの類似構造を有していることが分かる.

一方，同試料を $1500^{\circ} \mathrm{C}$ 以で焼結させたところ，密度が低 下する傾向が認められた．微細組織を観察した結果，図 6 に示 すように, 直径 $10 \sim 50 \mu \mathrm{m}$ 程度の球状の気泡が各所に存在す る様子が観察され，しかもその気泡は $1500^{\circ} \mathrm{C}$ 㛙結体よりも $1600^{\circ} \mathrm{C}$ で焼結した試料でより顕著に認められた。このような 気泡の存在は $1400^{\circ} \mathrm{C} て ゙$ 焼結した試料では認められていない。

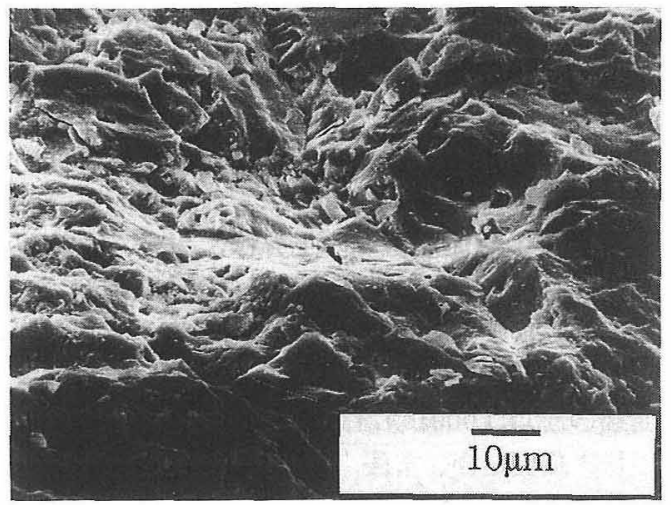

Fig. 5. Fracture surface of the pollucite ceramics sintered at $1400^{\circ} \mathrm{C}$ for $4 \mathrm{~h}$

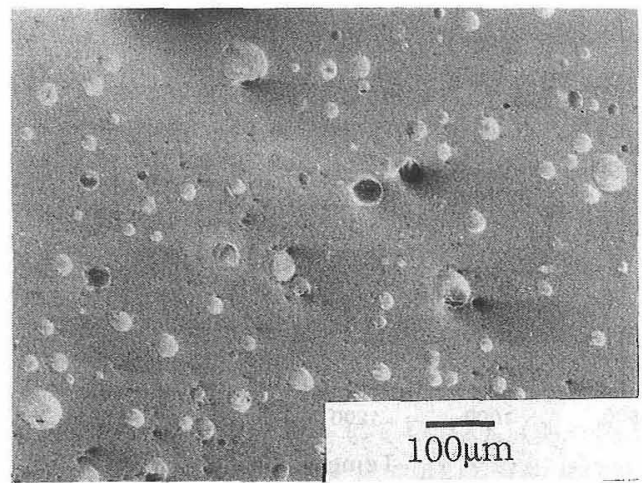

Fig. 6. Cross section of the pollucite ceramics sintered at $1600^{\circ} \mathrm{C}$ for $4 \mathrm{~h}$.
ガラスセラミックス合成における発泡現象は， $\beta$-久ポジュメン の熱処理などに伴って起こる場合があることが知られてお り11),13，14， ガラス中の溶解しているガス成分の遊離に起因す ることが報告されている．本試料の X 線による相同定の結果 からは, $1400^{\circ} \mathrm{C} て ゙$ 焼結した試料と同様にポルーサイトのみが 結晶相として検出されており，過剰のシリカ，アルミナ成分は ガラス質相を形成しているものと考えられる。したがって，本 試料においても残存ガラス相からのガス分離が発泡の原因と推 察される. 特に, 本実験ではガラス合成の出発原料として炭酸 セシウムを使用している．この炭酸セシウムは合成過程で $500 \sim 1000^{\circ} \mathrm{C}$ 付近で熱分解し，酸化セシウムになると同時に多 量の炭酸ガスを生成する，炭酸ガスは各種の溶融ガラス中に溶 解することは知られており，本実験においても，ガラス溶融段 階で生成した炭酸ガスの一部がガラス中に溶解していた可能性 は十分考えられる.ガラス中に溶融していた炭酸ガスは，ポ ルーサイトの結晶化が進行するにつれて残存ガラス相内に濃縮 されていくが，熱処理温度の上昇に伴ってガラス相中の炭酸ガ

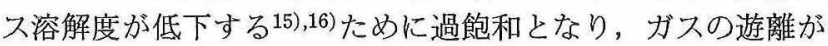
起こる. 一方, 焼結体は既に縹密質となっているため, 放出さ れたガスは系外に揮散することができず，焼結体内に残留し，

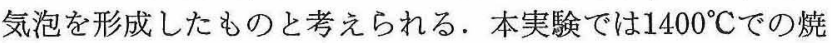
結では十分緻密な然結体が得られているにもかかわらず, 気泡 の生成は認められないことから， $1400^{\circ} \mathrm{C}$ と $1500^{\circ} \mathrm{C}$ の間に炭酸 ガスの過飽和と遊離が起こるクリティカルポイントが存在する と推定される。一方，このことはポルーサイト合成時の組成制 御の重要性を示唆している.すなわち，セシウム源として炭酸 セシウムのようなガス成分の放出を伴う原料を使用する場合 は, 組成を極力ポルーサイトの量論比に近づけて残留ガラスの 生成量を抑制するとともに，ガラス軟化から結晶化が始まる比 較的低い温度領域で結晶化を促進させて溶融ガスの放出を促進 することが必要と思われる。

図 7 に $1400^{\circ} \mathrm{C} て ゙$ 焼結した試料を用いて測定した室温，及び 高温曲げ強度の測定結果を示す．図に示したように，本焼結体 の平均室温強度は $102 \mathrm{MPa}$ であるが，1000 $\mathrm{C}$ 及び $1200^{\circ} \mathrm{C}$ では それぞれ128 MPa, $130 \mathrm{MPa}$ と室温よりむ高い強度を示した。 この原因の一つとして，加工，研削による曲げ試験片作製時の 加工傷が高温でヒーリングされたこ上が考えられる.しかし， ポルーサイトと同様に高融点を持ち，高温特性改善が期待でき

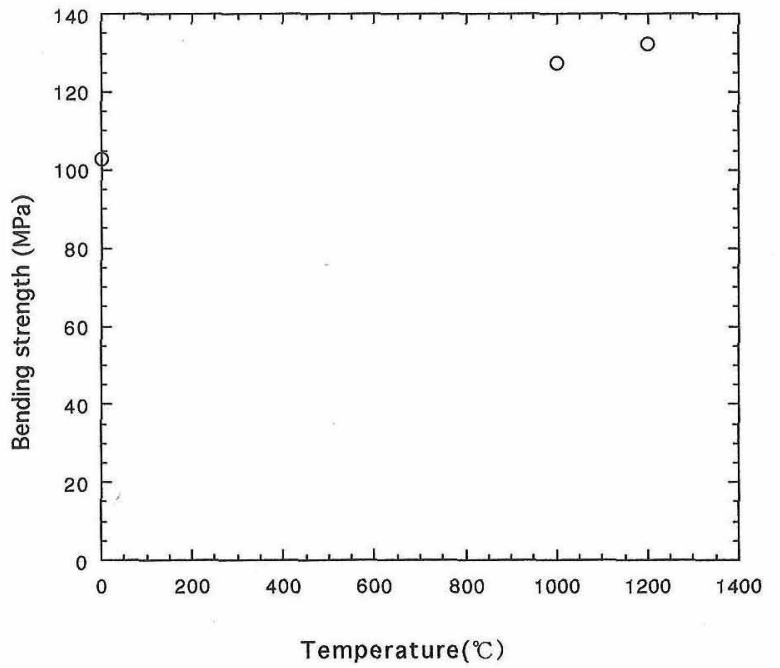

Fig. 7. Relationship between temperature and bending strength of the pollucite ceramics. 
Table 2. Physical and Mechanical Properties of the Sample Sintered at $1400^{\circ} \mathrm{C}$ for $4 \mathrm{~h}$ in Air

\begin{tabular}{|c|c|c|c|c|c|}
\hline \multirow{2}{*}{ Sample } & \multirow{2}{*}{$\begin{array}{l}\text { Bulk } \\
\text { density } \\
\left(\mathrm{g} / \mathrm{cm}^{3}\right)\end{array}$} & \multirow{2}{*}{$\begin{array}{l}\text { Thermal } \\
\text { expansion } \\
\text { coefficient } \\
\left(10^{-6} /{ }^{\circ} \mathrm{C}\right)\end{array}$} & \multirow{2}{*}{$\begin{array}{c}\text { Young's } \\
\text { modulus } \\
\text { (GPa) }\end{array}$} & \multicolumn{2}{|c|}{ Bending strength } \\
\hline & & & & $\begin{array}{l}\text { R. T. } \\
\text { (MPa) }\end{array}$ & $\begin{array}{c}1000^{\circ} \mathrm{C} \\
(\mathrm{MPa})\end{array}$ \\
\hline & 2.8 & 2.7 & 100 & 102 & 128 \\
\hline
\end{tabular}

るセルシアンを本実験と同じプロセスで作製した場合, 残留ガ

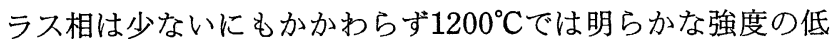
下が認められている18). 本ポルーサイト質焼結体では比較的 多量のガラス質相が残留しており, 特に $1200^{\circ} \mathrm{C} て ゙$ 破断した試 料ではクリープ現象が認められることから, 焼結体中の残存ガ ラス相が強度を支配していることは明らかである. それにもか かわらず高温強度の低下が認められなかったことは興味深く, 組成をポルーサイトの量論比に近づけてガラス相の残留を抑制 することによって, より高温強度の改善が期待できるものと思 われる。

表 2 に $1400^{\circ} \mathrm{C} て ゙ ~ 4 \mathrm{~h}$ 焼結した試料の各物性值を示す．低膨 張材料としての重要な物性値である熱膨張率は, 室温から

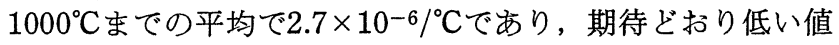
を示すことが確認された.このうち, 室温から $300^{\circ} \mathrm{C}$ 範囲で は3.2 $\times 10^{-6} /{ }^{\circ} \mathrm{C}$ と比較的高い值を示しており, 報告されている 低温側での熱膨張と似た挙動を示した ${ }^{9), 10)}$ 。 また，300〜 $600^{\circ} \mathrm{C}$ 範囲ではポルーサイトの熱膨張率はほほゼロであるこ とが報告されているが, 本実験ではわずかではあるが熱膨張が

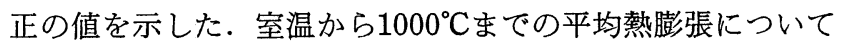
は小林ら 10)の報告しているシリカ過剰組成のポルーサイトの 值 $\left(2.6 \times 10^{-6} /{ }^{\circ} \mathrm{C}\right)$ と良く一致しており, 本試料中のポルーサ イト結晶は量論比と比較してシリカ過剰組成となっている可能 性が考えられる.これらの結果より, 本実験で得られたポルー サイト質ガラスセラミックス中のガラス相の存在は, ポルーサ イト特有の高温特性, 熱膨張挙動性についてその特性を大きく 損なわないことを示唆している.

\section{4. 結 論}

アーク溶融法により, ポルーサイト組成混合粉末を溶融, 急 冷することによってガラス体を作製し，その粉砕粉末により焼 結実験を行った結果以下のような知見を得た.

（1）アーク溶融法により得られたガラスは出発組成と比較 し, 溶融段階でのセシウム成分の揮発が起こり, 酸化セシウム 成分が低下することが認められた。

（2）得られたガラス粉末を用い作製した試料を $1400^{\circ} \mathrm{C}, 4 \mathrm{~h}$
の温度で焼結を行うことによってかさ密度 $2.85 \mathrm{~g} / \mathrm{cm}^{3}$ の緻密 なポルーサイト質ガラスセラミックス焼結体を作製することが でき，その緻密化はガラスの粘性流動によって起こることが示 された。

（3）得られたポルーサイト質焼結体について熱膨張率, 室 温の弾性率, 室温曲げ強度, 高温曲げ強度を測定した。 その結 果, 熱膨張率は $2.7 \times 10^{-6} /{ }^{\circ} \mathrm{C}$, 室温の弾性率は $100 \mathrm{GPa}$, 室温 強度は102 MPa，高温強度 $\left(1000^{\circ} \mathrm{C}\right)$ は $128 \mathrm{MPa}$ であった。

謝辞 本研究は通商産業省工業技術院産業科学技術研究開 発「シナジーセラミックスの研究開発」の一環としてファインセ ラミックス技術組合が新エネルギー・産業技術総合開発機構によ り委託を受け, シナジーセラミックス研究体に属する著者らに よって行われたものである.

\section{文 献}

1) S. Udagawa and H. Ikawa, Ceramics Japan, 14, 967-76 (1979) [in Japanese].

2) G. H. Beall and H. L. Rittler, "Glass-Ceramics from Pollucite," U.S. Patent 3,723,140.

3) M. A. Hogan and S. H. Risbud, J. Mater. Res., 6, 217-19 (1991).

4) R. Dimitrijevic, V. Dondur and N. Petranovic, J. Solid State Chem., 95, 335-45 (1991).

5) D. W. Richerson and F. A. Hummel, J. Am. Ceram. Soc., 55, 269-73 (1972).

6) D. Taylor and C. M. B. Henderson, Am. Mineral., 53, 147689 (1968).

7) H. Kobayashi, I. Yanase and T. Mitamura, J. Am. Ceram. Soc., 80 2161-64 (1997).

8) JCPDS 29-407.

9) H. Kobayashi, T. Terasaki, T. Mori, C. Ishihara, S. Saitoh, H. Yamamura and T. Mitamura, J. Ceram. Soc. Japan (Seramikkusu Ronbunshi), 99, 686-91 (1991) [in Japanese].

10) H. Kobayashi, T. Terasaki, T. Mori, H. Yamamura and T. Mitamura, J. Ceram. Soc. Japan, 100, 91-93 (1992) [in Japanese].

11) H. Scholze, Glass Ind., 47, 546-51 (1966).

12) G. V. Samsonov, "Saishin Sankabutsu Binran," Nisso Tsushin-Sha (1989) p. 61 [in Japanese].

13) H. Kobayashi, N. Ishibashi, T. Akiba and T. Mitamura, $J$. Ceram. Soc. Japan (Seramikkusu Ronbunshi), 98, 703-08 (1990) [in Japanese].

14) H. Kobayashi, N. Ishibashi, T. Akiba and T. Mitamura, $J$. Ceram. Soc. Japan (Seramikkusu Ronbunshi), 98, 1023-28 (1990) [in Japanese].

15) M. L. Peace, J. Am. Ceram. Soc., 48, 175-78 (1965).

16) M. L. Peace, J. Am. Ceram. Soc., 47, 342-46 (1964).

17) I. A. Aksay, J. A. Pask and R. F. Davis, J. Am. Ceram. Soc., 62, 332 (1979).

18) N. Miyagawa, N. Shinohara and M. Okumiya, J. Ceram. Soc. Japan, 107, 555-60 (1999) [in Japanese]. 